\title{
Varietal Evaluation and Clustering of Early Maize Genotypes in Mid-Western Hilly Region of Nepal
}

\author{
Bishnu Prasad KANDEL ${ }^{1^{*}}$ \\ ${ }^{1}$ Department of Plant Breeding, Institute of Agriculture and Animal Science, Tribhuvan University, Kirtipur 44618, Nepal \\ * corresponding author: bkandel33@gmail.com
}

Bulletin UASVM series Agriculture 77(2) / 2020

Print ISSN 1843-5246; Electronic ISSN 1843-5386

DOI:10.15835/buasvmcn-agr: 2020.0014

\begin{abstract}
Eleven early maize (Zea mays) genotypes were evaluated for their yield and yield component traits at the research block of Regional Agriculture Research Station (RARS) Lumle, Kaski, Nepal during Kharif season of 2016. The experiment was laid out in randomized complete block design (RCBD) with three replications. Results showed that all the studied genotypes differed significantly for grain yield as well as other yield component traits except number of kernel per row. Out of tested genotypes COMPOZ-NIPB, EEYC1, POP-445/POP-446 were three top performer genotypes yielding 6.89, 5.38 and $5.19 \mathrm{t} \mathrm{ha}^{-1}$. Early mid Katamari, Rajahar local, Manakamana-5, EEYC1 were statistically at par with Arun-4(standard check) and will be needed further evaluation and improvement by a selection of desirable traits. Eleven genotypes occupied three different clusters and showed that early maize genotypes suggest considerable genetic diversity among themselves. Genotypes belong to cluster one having the highest yield potentials so need to be further evaluation in different location of mid hill and recommended best variety for that domain.
\end{abstract}

Key words: early maize, grain yield, performance evaluation, cluster analysis

\section{INTRODUCTION}

Maize is the second most important staple cereal food in terms of area and production in Nepal (MoAD, 2017/18). At present, the maize sown area in Nepal is $9,24,321$ ha with a total production of 23,36,675 MT and productivity of 2.53 t ha $^{-1}$ (MoAD, 2017/18). Ranum et al. (2014) reported that $98 \mathrm{~g} /$ person/day was the per capita maize consumption in Nepal, that was the highest in South Asia. It is a principal food crop of the hilly farmers and source of animal feed for different feed industries in theTerai region of Nepal (KC et al., 2015). Maize is considered as Kharif season crop in the hilly and mountainous areas, but it can be successfully cultivated both kharif and rabi season in Terai and inner Terai.

Early maize matures 15-25 days earlier than normal season maize. Generally, it's mature 90-130 days after sowing allow growing of the short duration crops like coriander, radish etc. which increase the cropping intensity as well as farmer income. The existing cropping patterns are maize-wheat, maize-barley, maize-potatoes, maize-fallow, ricemaize-maize, and farmers use a shorter duration of maize varieties to catch the winter crops. Early maize has only the option in rice-maize-maize system in the unirrigated land of terai. The adoption rate of improved maize varieties is low in eastern and western mid-hills than Terai (Gurung, 1999). It might be due to the longer duration of improved maize varieties which could not fit in the cropping pattern. Kunwar et al. (2014) also reported there are limited option of higher yielding early maize for maize growers which could suited to different cropping pattern. So, there is a need for improved early maize varieties that could fit in the cropping 
pattern and raise productivity. There were few researches were carried out to evaluate early maize in Nepal. Previous researcher such as Prasai et al. (2013) evaluate eight early maize with two check varieties at RARS Doti during 2011/12-2012/13. Dhakal et al. (2017) evaluate 14 early maize at RARS Doti during 2015-2016. Kandel et al. (2017) studied genetic variability of early maize at RARS Lumle. The present study was carried out with objectives to evaluate available early maize genotypes in term of yield potentials, flowering and maturity behaviors.

\section{MATERIALS AND METHODS}

A varietal trail on early maize genotypes was conducted at the research farm of RARS Lumle during Kharif 2016. Eleven maize genotypes were laid out in RCBD design with three replications. The research station is situated at an altitude of 1740 meters above mean sea level in the southfacing slopes at $28.29^{\circ}$ north and $83.81^{\circ}$ east coordinates. Each genotype received the plots of 9 $\mathrm{m}^{2}$ area with the net plot area of $99 \mathrm{~m}^{2}$ per block/ replication. Each plant received $75 \mathrm{~cm} \times 25 \mathrm{~cm}$ crop geometry. Initially, two seeds per hill were sown and later on one plant was thinned to maintain single plant per hill. Fertilizer was applied at the rate of 120:60:40 NPK kg ha-1 . Nitrogen was applied in two splits dose first at knee-high and second as pre-tasseling/silking stages. Recommended cultural and crop protection practices were followed. All the data were obtained from sample row from ten randomly selected plant except for phenological traits such as 50\% tasseling, 50\% silking and maturity days. Observation on yield and yield component such as number of kernels per row, number of kernel rows per ear, ear length $(\mathrm{cm})$, ear diameter $(\mathrm{cm})$, ear weight $(\mathrm{g})$ and test weight $(\mathrm{g})$ and grain yield ( $\mathrm{t} \mathrm{ha}^{-1}$ ) after moisture adjustment at $12.5 \%$. Similarly, observations made on growth traits such as plant height $(\mathrm{cm})$ and ear height $(\mathrm{cm})$. Ear aspect was a score on a scale of 1 to 5 where, 1 = clean, uniform, large and well-filled ears and 5 = rotten, variable, small, and partially filled ears (UPOV Maize 2009). All the collected data were entered into MS Excel and statistical analysis by using computer software's statistical package R version 3.6.0 and clustering of genotypes was carried out by Minitab version 14.

\section{RESULTS AND DISCUSSIONS Mean Performance and Analysis of Vari- ance \\ Phenological traits}

The result revealed that genotypes have significantly differed for days to $50 \%$ tasseling (Table 2). Genotypes such as Rajahar local and EEYC1 had delayed $50 \%$ tasseling days as compared to Arun-4 (Standard check) and remaining genotypes were statistically at par with Arun-4. It reflected that all mention genotypes had $50 \%$ tasseling days of 60-70 after sowing. The genotypes were highly significant for $50 \%$ silking days shown

Table 1. List of genotypes used in research

\begin{tabular}{cll}
\hline Entry No. & Treatments & \multicolumn{1}{c}{ Source } \\
\hline 1 & Early mid Katamari & NMRP, Rampur \\
\hline 2 & Rajahar local & NMRP, Rampur \\
\hline 3 & S97TEYGHAYB(3) & NMRP, Rampur \\
\hline 4 & POP-445/POP-446 & NMRP, Rampur \\
\hline 5 & COMPOZ-NIPB & NMRP, Rampur \\
\hline 6 & R.C/POOL-17 & NMRP, Rampur \\
\hline 7 & SO3TEY/LN & NMRP, Rampur \\
\hline 8 & Arun-4 (standard check) & NMRP, Rampur \\
\hline 9 & Manakamana-5 (local check) & NMRP, Rampur \\
\hline 10 & ZM-621/POOL-15 & NMRP, Rampur \\
\hline 11 & EEYC1 & NMRP, Rampur \\
\hline
\end{tabular}


in Table 2. The result showed that all studied genotypes were statistically at par with Arun-4. Prasai et al. (2014) evaluated nine early maize genotypes in Doti during 2011/12 -2012/13 reported that male and female flowering period ranges from 36-51 and 41-54 respectively which was earlier than our findings. Kuwnar et al. (2014) also reported variation of flowering in early maize which is also accordance to our findings. Maturity days were highly significant for studied genotypes (Table 3). Rajahar local which was late maturing genotype whereas genotypes such as Early mid Katamari, R.C/POOL-17, SO3TEY/LN, ZM-621/ POOL-15, Manakamana -5 and POP-445/POP446 were earlier maturing genotypes that were statistically at par. Sharma et al. (2018) evaluate ten maize genotypes at Rampur, Nepal reported significant different for a phenological trait which was according to our findings.

\section{Growth traits}

The result showed a highly significant difference in the plant height for the genotypes (Table 2). Maximum plant height had been shown by COMPOZ-NIPB and minimum PH had been shown by Rajahar local, Early mid Katamari was statistically similar to Arun-4. The observed diffe- rence in plant height between the genotypes must be due to genetic variation present in the population. Our findings partially agreed with Ali (1994). However, he reported that variation in plant height is genetic as well as environmental influences. Ear height also significantly differ for all the studied genotypes (Table 2). Maximum ear height had been shown by COMPOZ-NIPB and minimum ear height had been shown by Rajahar local, Early mid Katamari, POP-445/POP-446, SO3TEY/LN and MANAKAMANA-5 were found statistically at par with Arun-4 (Table 2). Parsai et al. (2014) reported significant differences were for growth traits, which was according to our findings.

\section{Yield and yield components traits}

The result showed a significant difference in no. of kernel row per ear (NKRPE) for genotypes (Table 3). Highest NKRPE has been observed in R.C/POOL-17 and lowest has been shown by Early mid Katamari. Genotypes S97TEYGHAYB(3), POP445/POP-446, COMPOZ-NIPB, SO3TEY/LN and Manakamana- 5 were statistically at par with Arun4 . The result showed non-significant difference in no. of kernel per ear (NKPR) for the genotypes (Table 3). Ghimire et al. (2015) in their experiment variety S97TEYGHAYB(3), Rajahar local, POP-445/

Table 2. Means for yield and yield attributes of eleven early maize genotypes at RARS, Lumle, Nepal, 2016

\begin{tabular}{lcccccc}
\hline \multirow{2}{*}{$\begin{array}{c}\text { Mean treatment } \\
\text { Genotypes }\end{array}$} & TD & SD & PH (cm) & EH (cm) & ED (cm) & EL (cm) \\
\cline { 2 - 7 } & $62^{\mathrm{c}}$ & $64^{\mathrm{ab}}$ & $191^{\mathrm{abc}}$ & $92^{\mathrm{abc}}$ & $3.99^{\mathrm{abc}}$ & $14.1^{\mathrm{b}}$ \\
\hline Early mid Katamari & $70^{\mathrm{a}}$ & $70^{\mathrm{a}}$ & $152^{\mathrm{c}}$ & $73^{\mathrm{c}}$ & $4.18^{\mathrm{ab}}$ & $16.9^{\mathrm{ab}}$ \\
\hline Rajahar local & $62^{\mathrm{bc}}$ & $64^{\mathrm{ab}}$ & $173^{\mathrm{bc}}$ & $80^{\mathrm{bc}}$ & $4.02^{\mathrm{ab}}$ & $14.4^{\mathrm{b}}$ \\
\hline S97TEYGHAYB(3) & $64^{\mathrm{bc}}$ & $66^{\mathrm{ab}}$ & $179^{\mathrm{bc}}$ & $89^{\mathrm{abc}}$ & $4.10^{\mathrm{ab}}$ & $14.8^{\mathrm{b}}$ \\
\hline POP-445/POP-446 & $64^{\mathrm{abc}}$ & $67^{\mathrm{ab}}$ & $228^{\mathrm{a}}$ & $119^{\mathrm{a}}$ & $4.22^{\mathrm{ab}}$ & $18.7^{\mathrm{a}}$ \\
\hline COMPOZ-NIPB & $62^{\mathrm{c}}$ & $62^{\mathrm{b}}$ & $178^{\mathrm{bc}}$ & $82^{\mathrm{bc}}$ & $4.06^{\mathrm{ab}}$ & $14.2^{\mathrm{b}}$ \\
\hline R.C/POOL-17 & $68^{\mathrm{ab}}$ & $68^{\mathrm{ab}}$ & $208^{\mathrm{ab}}$ & $105^{\mathrm{ab}}$ & $3.59^{\mathrm{c}}$ & $14.8^{\mathrm{b}}$ \\
\hline SO3TEY/LN & $63^{\mathrm{bc}}$ & $65^{\mathrm{ab}}$ & $193^{\mathrm{abc}}$ & $105^{\mathrm{ab}}$ & $3.93^{\mathrm{bc}}$ & $13.9^{\mathrm{b}}$ \\
\hline Arun-4(standard check) & $65^{\mathrm{abc}}$ & $66^{\mathrm{ab}}$ & $182^{\mathrm{bc}}$ & $91^{\mathrm{abc}}$ & $4.22^{\mathrm{ab}}$ & $15.2^{\mathrm{b}}$ \\
\hline Manakamana-5 (local check) & $66^{\mathrm{abc}}$ & $70^{\mathrm{a}}$ & $181^{\mathrm{bc}}$ & $86^{\mathrm{bc}}$ & $4.18^{\mathrm{ab}}$ & $14.4^{\mathrm{b}}$ \\
\hline ZM-621/POOL-15 & $66^{\mathrm{a}}$ & $68^{\mathrm{ab}}$ & $172^{\mathrm{bc}}$ & $80^{\mathrm{bc}}$ & $4.39^{\mathrm{a}}$ & $15.8^{\mathrm{ab}}$ \\
\hline EEYC1 & 5.50 & 5.13 & 36.26 & 26.78 & 0.34 & 2.84 \\
\hline LSD(0.05) & 4.25 & 4.05 & 11.57 & 17.28 & 4.97 & 11.05 \\
\hline CV(\%) & $*$ & $* *$ & $* *$ & $* *$ & $*^{*}$ & $* *$ \\
\hline F Test & 64.72 & 66.36 & 185.07 & 91.50 & 4.08 & 15.19 \\
\hline Grand mean & & & & & &
\end{tabular}

Note: $\left({ }^{* *}\right)$ significant at $0.01,\left({ }^{*}\right)$ significant at $0.05, \mathrm{~ns}=$ non-significant, $\mathrm{TD}=50 \%$ tasseling days, $\mathrm{SD}=50 \%$ silking days, $\mathrm{PH}=\mathrm{Plant}$ height, $\mathrm{EH}=\mathrm{Ear}$ height, $\mathrm{ED}=$ Ear diameter, $\mathrm{EL}=$ Ear length 
Table 3. Means for yield and yield attributes of eleven early maize genotypes at RARS, Lumle, Nepal, 2016

\begin{tabular}{lccccccc}
\hline \multirow{2}{*}{$\begin{array}{c}\text { Mean treatment } \\
\text { Genotypes }\end{array}$} & \multicolumn{7}{c}{ Characters } \\
\cline { 2 - 8 } & NKRPE & NKPR & EW (g) & TKW (g) & EA & DPM & GY (t ha- $^{\text {) }}$ \\
\hline Early mid Katamari & $12.0^{\mathrm{c}}$ & 28 & $55.64^{\mathrm{bc}}$ & $298.7^{\mathrm{ab}}$ & $3.3^{\mathrm{a}}$ & $116^{\mathrm{b}}$ & $4.44^{\mathrm{bc}}$ \\
\hline Rajahar local & $13.6^{\mathrm{ab}}$ & 24 & $60.64^{\mathrm{bc}}$ & $262.5^{\mathrm{b}}$ & $3.0^{\mathrm{ab}}$ & $125^{\mathrm{a}}$ & $4.72^{\mathrm{abc}}$ \\
\hline S97TEYGHAYB(3) & $13.0^{\mathrm{abc}}$ & 25 & $57.39^{\mathrm{bc}}$ & $256.0^{\mathrm{b}}$ & $3.5^{\mathrm{ab}}$ & $120^{\mathrm{ab}}$ & $4.02^{\mathrm{bc}}$ \\
\hline POP-445/POP-446 & $12.9^{\mathrm{abc}}$ & 27 & $66.53^{\mathrm{ab}}$ & $272.9^{\mathrm{ab}}$ & $3.6^{\mathrm{a}}$ & $119^{\mathrm{b}}$ & $5.19^{\mathrm{abc}}$ \\
\hline COMPOZ-NIPB & $13.1^{\text {abc }}$ & 29 & $84.8^{\mathrm{a}}$ & $331.7^{\mathrm{a}}$ & $2.1^{\mathrm{b}}$ & $122^{\mathrm{ab}}$ & $6.89^{\mathrm{a}}$ \\
\hline R.C/P0OL-17 & $14.2^{\mathrm{a}}$ & 23 & $53.76^{\mathrm{bc}}$ & $268.5^{\mathrm{ab}}$ & $3.5^{\mathrm{a}}$ & $116^{\mathrm{b}}$ & $3.94^{\mathrm{bc}}$ \\
\hline SO3TEY/LN & $13.3^{\mathrm{abc}}$ & 25 & $41.41^{\mathrm{c}}$ & $240.7^{\mathrm{b}}$ & $3.1^{\mathrm{a}}$ & $118^{\mathrm{b}}$ & $2.97^{\mathrm{c}}$ \\
\hline Arun-4(standard check) & $12.2^{\mathrm{bc}}$ & 26 & $52.17^{\mathrm{bc}}$ & $285.3^{\mathrm{ab}}$ & $3.0^{\mathrm{ab}}$ & $122^{\mathrm{ab}}$ & $5.76^{\mathrm{ab}}$ \\
\hline Manakamana-5(local chk) & $13.5^{\mathrm{abc}}$ & 26 & $60.09^{\mathrm{bc}}$ & $305.3^{\mathrm{ab}}$ & $3.6^{\mathrm{a}}$ & $119^{\mathrm{b}}$ & $4.89^{\mathrm{abc}}$ \\
\hline ZM-621/POOL-15 & $13.7^{\mathrm{ab}}$ & 23 & $57.4^{\mathrm{bc}}$ & $283.7^{\mathrm{ab}}$ & $3.0^{\mathrm{ab}}$ & $118^{\mathrm{b}}$ & $4.63^{\mathrm{bc}}$ \\
\hline EEYC1 & $13.7^{\mathrm{ab}}$ & 27 & $69.06^{\mathrm{ab}}$ & $304.5^{\mathrm{ab}}$ & $3.6^{\mathrm{a}}$ & $121^{\mathrm{ab}}$ & $5.38^{\mathrm{ab}}$ \\
\hline LSD(0.05) & 1.62 & 3.82 & 16.41 & 41.89 & 0.84 & 5.43 & 1.58 \\
\hline CV(\%) & 7.22 & 8.75 & 16.18 & 9.71 & 15.28 & 2.47 & 19.51 \\
\hline F Test & $*$ & $\mathrm{~ns}$ & $* *$ & $* *$ & $* *$ & $*^{*}$ & $* *$ \\
\hline Grand mean & 13.20 & 25.72 & 59.89 & 254.67 & 3.25 & 129 & 4.80 \\
\hline
\end{tabular}

Note: $\left({ }^{* *}\right)$ significant at $0.01,(*)$ significant at $0.05, \mathrm{~ns}=$ non-significant; $\mathrm{EA}=\mathrm{Ear}$ aspect, EL=Ear length, ED=Ear diameter, EW=Ear weight, NKRPE=Number of kernel row per ear, NKPR=Number of kernel per row, TKW=Thousand kernel weight, DPM=Days to physiological maturity, GY=Grain yield .

Table 4. Agro-morphology and yield components traits of early maize genotypes within and among three cluster

\begin{tabular}{lccc}
\hline \multicolumn{1}{c}{ Variables } & Cluster $\mathbf{1}$ & Cluster $\mathbf{2}$ & Cluster 3 \\
\hline 50 \% tasseling days & 75.81 & 77.78 & 77.33 \\
\hline $50 \%$ silking days & 74.61 & 74.44 & 77.000 \\
\hline Maturity days & 129.57 & 131.22 & 128.33 \\
\hline Plant height & 178.41 & 196.24 & 198.17 \\
\hline Ear height & 87.35 & 99.17 & 97.59 \\
\hline Ear length & 14.85 & 16.36 & 14.09 \\
\hline Ear diameter & 4.06 & 4.24 & 3.72 \\
\hline Ear weight & 57.42 & 70.89 & 13.22 \\
\hline Number of kernel row & 13.28 & 13.22 & 23.64 \\
\hline Number of kernel per row & 25.20 & 27.89 & 216.79 \\
\hline Test weight & 247.73 & 283.51 & 3.21 \\
\hline Grain yield & 4.59 & 5.82 & \\
\hline
\end{tabular}


POP-446, SO3TETEY/LN, EEYC1, Pool-27, Pool-15 were statistically similar to Arun-2.

The result showed the highly significant difference in ear diameter for genotypes (Table 2).The highest ear diameter was observed in EEYC1 and the lowest has been found in SO3TEY/LN. The genotypes were highly significant for ear length in which the highest EL has been shown by COMPOZNIPB and minimum has been shown by Early mid Katamari, Rajahar local, S97TEYGHAYB(3), POP-445/POP-446, R.C/POOL-17, SO3TEY/LN, Manakamana-5 and ZM-621/POOL-15 were statically at par with Arun-4 . Highly significant difference obtained in ear weight for the genotypes. Maximum ear weight had been shown in COMPOZNIPB and minimum had been showed in SO3TEY/ LN, Early mid Katamari, Rajahar local, R.C/POOL17 S97TEYGHAYB(3), Manakamana-5, ZM-621/ P0OL-15 were statistically similar to Arun-4 . The result demonstrated a highly significant difference in test weight for genotypes (Table 3). Maximum TKW has been shown by COMPOZ-NIPB and minimum were showed in S97TEYGHAYB (3), Rajahar local and SO3TEY/LN which were statistically at par. Ghimire and Timsina (2015) reported that Rajahar local has a low five hundred kernel weight which in accordance with our fin- dings. The result showed a highly significant difference in the grain yield $t \mathrm{ha}^{-1}$ for the genotypes. Among the tested genotypes, COMPOZ-NIPB has been found high yield potential and genotype SO3TEY/LN had the lowest yielder. The genotypes POP-445/POP-446, Farmers variety and EEYC1, were found to be statistically at par with ARUN-4 for grain yield kg ha-1 ${ }^{-1}$ COMPOZ-NIPB, POP-445/POP446, and EEYC1 were the promising early maize genotype at mid-hill condition of Nepal. Arun-2, POP 445 and EEYC1 were identified as superior genotypes of maize (early) in the coordinate varietal trail (CVT) experiment of 2013 (Prasai et al., 2015), which was in accordance with this finding. Kunwar et al. (2016) reported that Arun4 were better adapted for Kabre and Pakhribas whereas pool-17 for Rajahar environments. Prasai et al. (2014) reported contradict finding in which SO3TEY/LN has the highest yield potential at lower hills and river basin agro-environment of far western hill of Nepal but in our case, SO3TEY/ LN had the lowest yield. This is because, SO3TEY/ LN has low thousand kernel weight, low ear length and highest ear aspect were recorded in this experiment.

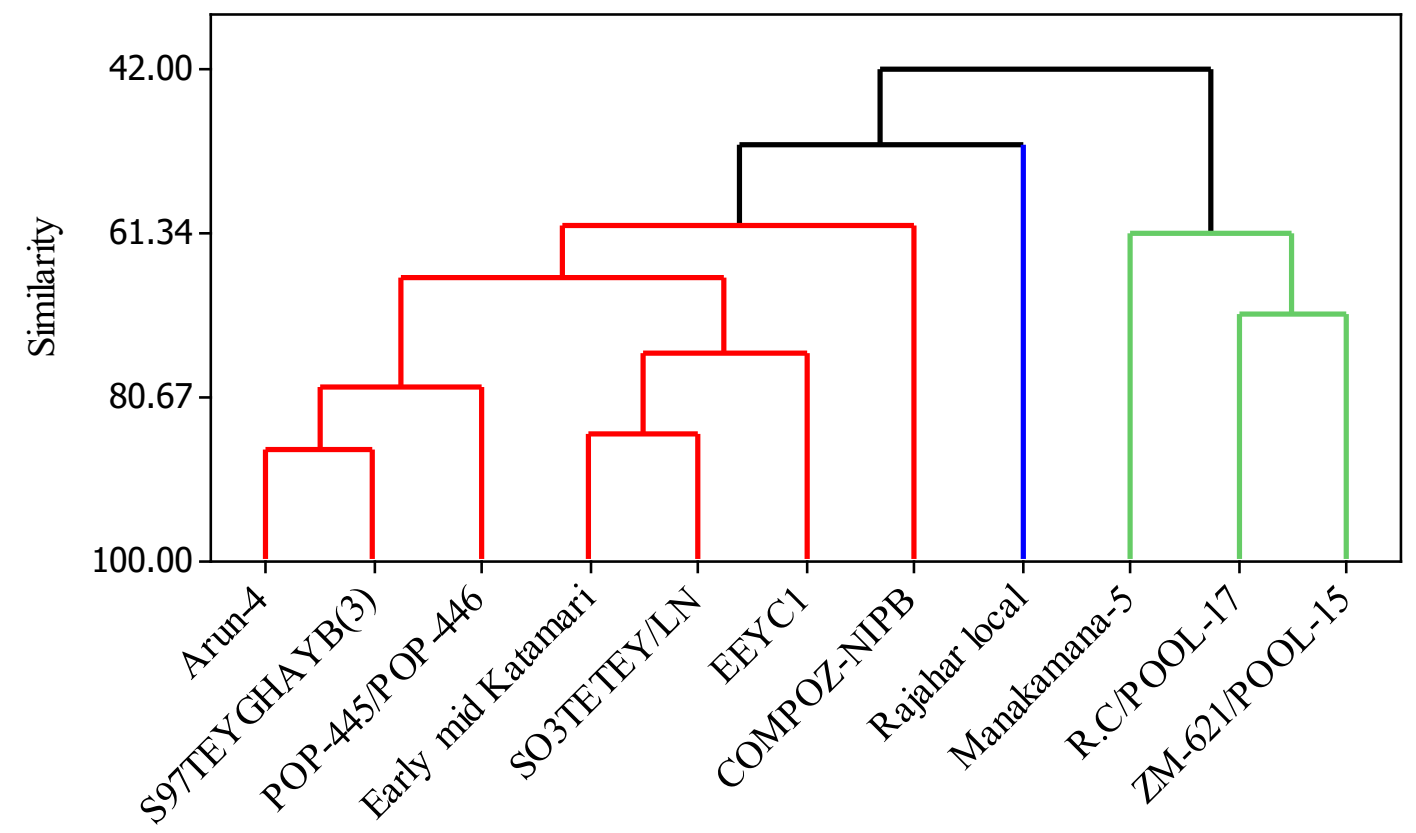

Observations

Figure 1. Clustering of early maize genotypes based on agro-morphological and yield components traits 


\section{Ear Aspect (EA)}

The highly significant differences obtained in EA for the genotype (Table 2). Maximum ear aspect reported for EEYC1 whereas minimum for COMPOZ-NIPB. COMPOZ-NIPB has low ear aspect value (i.e. cob is less damage) which ultimately gives higher grain yield. With an increase in the value of ear aspect (i.e. cob is more damage) which ultimately reduced the grain yield.

\section{Cluster analysis}

Cluster analysis is frequently used to classify maize accessions and can be used by breeders to identify accessions that have potential utility for specific breeding. Many researchers such as Kandel et al. (2019), Rohman et al. (2015) etc, used to classify maize accession by using cluster analysis. Eleven early maize genotypes were grouped into 3 clusters based on various agro-morphological and yield components traits (Figure 1). Cluster I consists of seven genotypes having the lowest plant and ear height and medium yielder. Cluster II consists of one genotype having early silking but delay maturity with the highest ear length, ear weight, ear diameter, no. of kernel per row, test weight and grain yield. Cluster III consists of 3 genotypes with delay silking and early maturity with the lowest ear length, ear diameter, ear weight, test weight, no. of kernel per ear, no. of kernel per row and the lowest grain yield, however, plant height was maximum. Kandel et al. (2019) also groped 10 hybrid maize genotypes in three different clusters.

\section{CONCLUSION}

From the analysis of data, all studied genotypes were flowering at 60-70 days after sowing. COMPOZ-NIPB, EEYC1 and POP-445/POP-446 were top yielder genotypes. Early mid Katamari Rajahar local, POP-445/POP-446, EEYC1 and Manakamana-5 were statistically at par with the standard check. These genotypes need to be included for further testing in farmer field trail. In case of maturity behaviour Early mid katamari , R.C/ POOL-17 and SO3TEY/LN were earlier maturity whereas Rajahar local mature later. Cluster analysis showed that genotypes possess variability so occupied three different clusters. Top yielder genotypes belong to cluster 1 .

\section{Acknowledgements}

Authors are grateful to the regional director, crop research unit \& the whole RARS Lumle team for their technical support for conducting research. Our sincere acknowledgment goes to Nepal Agricultural Research Council (NARC) for funding and National Maize Research Program (NMRP), Rampur, Chitwan for providing the genetic materials for the experiment.

\section{REFERENCES}

1. Ali Z (1994). Studies on comparative economic returns of different maize genotypes. M.Sc. Thesis, Dept. Agron., Univ. Agri., Faisalabad.

2. Dhakal B, Shrestha KP, Joshi BP, Shrestha J (2017). Evaluation of early maize genotypes for grain yield and agromorphological traits. Journal of Maize Research and Development, 3 (1): 67-76.

3. Ghimire B, Timsina D (2015). Analysis of Yield and Yield Attributing Traits of Maize Genotypes in Chitwan, Nepal. World Journal of Agricultural Research, 3(5): 153-162.

4. Ghimire B, Timsina D, Nepaln J (2015). Analysis of chlorophyll content and its correlation with yield attributing traits on early varieties of maize (Zea mays L.). Journal of Maize Research and Development, 1(1): 134145.

5. Gurung DB (1999). Potentials and Contraints of the maize based cropping system in the mid and Far Western hills of Nepal. A Survey Report. HARP PP01/98. Report No. 2.

6. Gurung DB, KC DB, Ortiz Ferrara G, Gadal N, Pokhrel S, Bhandari DR, Koirala KB, Bhandari BR, Tripathi M (2011). Maize value chains in Nepal. Paper presented in the $11^{\text {th }}$ Asian Maize Conference held in China on 7-11 November.

7. Kandel BP, Adhikari NR, Poudel A, Tripathi MP (2019). Genetic variability estimate of hybrid maize genotypes in inner terai of Nepal. Azarian Journal of Agriculture, 6(6): 164-170.

8. Kandel BP, Poudel A, Sharma S, Subedi M (2017). Variability studies in yield attributing traits of early maize genotypes in western-hill of Nepal. Nepalese Journal of Agriculture Science, 15: 119-124.

9. KC G, Karki TB, Shrestha J, Achhami BB (2015). Status and prospects of maize research in Nepal. Journal of Maize Research and Development, 1(1): 1-9.

10. Kunwar CB, Katuwal RB, Thapa S, Shrestha J (2016). Grain yield stability of early maize genotypes. Journal of Maize Research and Development, 2(1): 94-99.

11. Kunwar CB, Bhurer KP, Paudel SP, Chhetri JB, Shrestha J (2014). Early and extra early maturity maize variety for terai, inner terai and foot hill of Nepal. In: YP Giri, YG Khadka, BN Mahato, BP Sah, SP Khatiwada, MR Bhatta, BK Chettri, AK Gautam, D Gauchan, AR Ansari, JD Ranjit, R Shrestha, B Sapkota (eds). Proceedings of the $27^{\text {th }}$ National Summer Crops Workshop, Vol. II, held on 18-20 th April 2013 at National Maize Research Program, Rampur, Chitwan, 78-81.

12. MoAD (2017/18). Statistical Information on Nepalese Agriculture 2015/16. Singa Durbar, Kathmandu Nepal: Ministry of Agriculture and Development, Agri-Business Promotion and Statistics Division. 
13. NMRP, (2016). Annual Report 2072/73 (2015/16) National Maize Research Program, NARC, Rampur, Chitwan, Nepal.

14. Prasai HK, Sharma S, Singh Kushwaha UK, Joshi B (2014). Varietal improvement of early maize for far western hills of Nepal. Proceeding of the $27^{\text {th }}$ National Summer Crop Workshop (vol.1) 18-20 ${ }^{\text {th }}$ April 2013.

15. Prasai HK, Singh Kushwaha UK, Joshi BP, Shrestha J (2015). Performance evaluation of early maize genotypes in far western hills of Nepal. Journal of Maize Research and Development, 1(1): 106-111.

16. Ranum P, Pena-Rosas JP, Garsia-Casal MN (2014). Global maize production, utilization and consumption. Annals of the New York Academy of Sciences, 1, 1312.
17. Rohman MM, Banik BR, Biswas A, Rahman MS (2015). Genetic diversity of maize (Zea mays l.) inbreds under salinity stress. Bangladesh Journal of Agricultural Research, 40(4): 529-536.

18. Sharma BK, Sharma S, Kandel BP, Shrestha J (2018). Varietal evaluation of promising maize genotypes. Azarian Journal of Agriculture, 5(4): 120-124.

19. UPOV, (2009). Maize (UPOV Code: ZEAAA_MAY) Zea mays L.: guidelines for the conduct of tests for distinctiveness, uniformity and stability. International Union for the Protection of New Varieties of Plants, Geneva. p 62. 